\title{
Reach to the Characters and Effects of Medieval Universities in Western Europe
}

\author{
Shiqin Liao ${ }^{1, a}$, Huigai $\mathrm{Li}^{2, \mathrm{~b}}$ \\ ${ }^{1}$ School of Fashion Engineering, Jiangxi Institute of Fashion Technology, Nanchang 330102, China \\ ${ }^{2}$ School of Fashion Engineering, Jiangxi Institute of Fashion Technology, Nanchang 330102, China \\ ashiqin871212@163.com, ${ }^{\mathrm{b}} 461807675 @ q q . c o m$
}

Keywords: characteristics; Medieval Universities; inherit; modern Universities; quality

\begin{abstract}
The medieval universities which came into being in the 12th century in Europe were the predecessor of the modern university. The modern university inherits from the medieval university not only the appellation of "university", but also its basic organization structure, academic system, academic freedom and teaching. The modern university is also pursuing inter-nationality as the medieval university did centuries ago. An exploration into the natural characteristic and age characteristics of medieval university will provide the research of the formation and development of characteristics of the modern university with historical and historical support. It is better for the modern university to obtain national and international competitions by promoting its education quality.
\end{abstract}

\section{Introduction}

A medieval university is a corporation organized during the High Middle Ages for the purposes of higher learning. The first institutions generally considered to be universities were established in Italy, England, France, Spain, and Portugal between 11th and 14th centuries for the study of the Arts and the higher disciplines of Theology, Law, and Medicine.[1]These universities evolved from much older Christian cathedral schools and monastic schools, and it is difficult to define the exact date at which they became true universities, although the lists of studia generalia for higher education in Europe held by the Vatican are a useful guide.

The word universitas originally applied only to the scholastic guild (or guilds)-hat is the corporation of students and masters-within the studium, and it was always modified, as universitas magistrorum, or universitas scholarium, or universitas magistrorum et scholarium. In the course of time, however, probably toward the latter part of the 14th century, the term began to be used by itself, with the exclusive meaning of a self-regulating community of teachers and scholars whose corporate existence had been recognized and sanctioned by civil or ecclesiastical authority."[2]

The characteristics of universities is the comprehension of "inheritance and environment", not only the inheritance of universities from generation to generation and the production of historical deposition, but also with the change of time and environment and the fruits of constant creation. Medieval Universities in Western Europe which was born in the 12th was the predecessor of the modern universities. At the birth of Medieval, Universities in Western Europe which were different from other social organizations and education organizations embodied the essence of universities. For example, the international universities disappeared gradually after the end of the medieval; however, the international universities have become more and more popular today. To some extent, the modern universities are going to the road of returning. Medieval Universities in Western Europe were called the flower of the wisdom in dark ages, that's because the enchanting characteristics to the belonging of Medieval Universities in Western Europe: presenting the personal attributes which were the religiousness, the inter-nationality and privilege under the special historical time, region and cultural background, also containing the degree system which was born in the medieval and college education putting have a job as its goal. 


\section{Medieval Universities in Western Europe presenting the essence of personnel}

As the theologian Pasquier Quense had said, the universities in medieval were built by the person. We can also say that Medieval Universities in Western Europe belonged to person. In the whole period of enlightenment, there was no library, no laboratory, no museum, no donation and building belonged to themselves in Medieval Universities in Western Europe. Medieval Universities in Western Europe contained the teachers and the students, and the universities were the merchant guilds of teachers and students, which catered to the exploration to the university not only the earliest but also the best. The universities, as an appellation, were the production of the medieval, appearing between the $12^{\text {th }}$ century and $13^{\text {th }}$ century at early, but not knowing the exact time. The word "university" originated from the Latin word "universitas" which means the union of all communities and persons. In that time, the students did not go to universities, but studium generale which means education center. [3]However, in the documents of Medieval Universities in Western Europe, universitas not studium generale were used frequently. In medieval, universitas were used to call all kinds of communication or union, such as league, merchant guilds, and fraternity. When universitas were used to call studium generale, according to different types, it could be classified into universitas of scholarium or universitas of students, which could be found in the early documents about the universitas. In the latter, universitas means university, they have the same meaning.

\subsection{Medieval Universities in Western Europe were the community of the professors}

To some extent, the reputation of Medieval Universities in Western Europe was brought by the famous professors who worked in Medieval Universities in Western Europe. Even a famous professor stands for a university, the left of a professor would lead to the loss of a group of students. Due to the rare textbooks and high cost of publishing in Medieval, the management to the book trade was owned by the universities, which were one of the most valuable privileges. The books in university were occupied by the professors of all subjects. The professors enjoyed the right of scholar freedom, mastering knowledge and imparting truth. The professors controlled the teaching of Medieval Universities in Western Europe. The professors had great space to teach what they thought necessary though there were not a lot of contents, but just limit to the textbooks. The professors could teach the students according to what they understood to the textbooks and hold lectures. In certain, the professors were the leaders of a university. [4]Just as England Lativ scholar, John of Solisbury who studied in Paris in the $12^{\text {th }}$ century had the impression to his professors of William of Conches and Bemard: the elegant and thorough analysis to the literature inspired my pursue. Besides, the professors in Medieval Universities in Western Europe were elites of the society, especially the professors of medicine doctors and civil law. The professors of theology obtained the position of bishop which was equal to the position of Cardinal. In that time, famous scholars Thomas Aquinas and Aibertus Magnus were all university professors. In order to keep the social status and self-esteem for the professors, they must manage the affairs in universitas.

\subsection{The students with diversification in Medieval Universities in Western Europe}

Medieval Universities in Western Europe were the communication of teachers and students, and the students were the main reason of existence for medieval universities. Compared to the teachers, the students changed according to the difference of time and place. In some rare research documents in Medieval, a lot of evil doings were recorded, and the evil students occupied more than half of the amount in medieval universities. Just as today's students called their parents for money, the students in Medieval Universities in Western Europe wrote their parents for money, which were the main contents of the letters. Their moral characters could be known from their works. The poetry theme of them were not all guzzle, pornographic or blasphemy. The direct evidence was the determined demand from the students of Law Department that the professors must assume the responsibility of imparting knowledge once they paid the tuition to the professors. The inferior position, adding to the superior status and requirement of students in medieval universities, brought the students university in Medieval which just existed in Medieval. Like today's universities, the students came from different countries and hierarchies. There were rich students in medieval universities, especially the students from the Department of Law, and some students were nobles. Of course, there were less 
nobility, urban residents and rich peasants. The rich peasants occupied most of the students. For many students, coming into universities not only meant the mission of mastering knowledge, but also enhance the social status. Universities degrees provided chances for them to work for the imperial organization. Famous scholar Robert Grosseteste was the son of peasant.

\section{The world latitude of Medieval Universities in Western Europe}

The world latitude of Medieval Universities in Western Europe incarnated the religiousness and inter-nationality. To some extent, the religiousness was the premise of the inter-nationality.

\subsection{The religiousness of Medieval Universities in Western Europe}

There is no doubt that Medieval Universities in Western Europe were the religious universities. The universities were not churches, but they inherited and kept the characters of universities. Of course, some franchises of the scholars in universities were declined under the intervene of the public right. Urbain $\mathrm{V}$ said to the students who obtained the subsidize from the church that I believe not all students who I teach will become priest, some of you will become priests or common clergyman, others will stay the world and become father of a family. However, the pope owned the monopoly right in the law teaching and certification award. Any new-built university must be authorized by the royal rescript. The pope expected that the universities not only provided qualified theologiest and lawyers, but also as a organization to play its role in daily lives. In the $13^{\text {th }}$ century, the pope tried to keep the monopoly status of Paris theology(Fig. 1). However, in the $14^{\text {th }}$ century, the concept will retreat to the authority decentralization, and the theology department will built in new or old university. To the contrary of people's imagination, the students in Medieval Universities in Western Europe who learned theology were less, that's because there were high requirement for the theology, expense cost for the textbooks, a long time to study and obtain the degree and certification. Generally speaking, at the age of 35, was the most youngest to obtain the certification. On in universities of Vienna and Clone, the students could obtain the degrees and certifications at the age of 30 if there were no other factors. As you know, the graduates from the theology must work in church. And there was a rule in university of Bologna that the graduate qualification was to obtain master's degree. Bologna University is the oldest university in the world (Fig. 2). Just the reasons mentioned in above, the theology students were becoming less and less. In church, the amount of the lawyers was more than the theologist. That's because the change of the church organization and function.

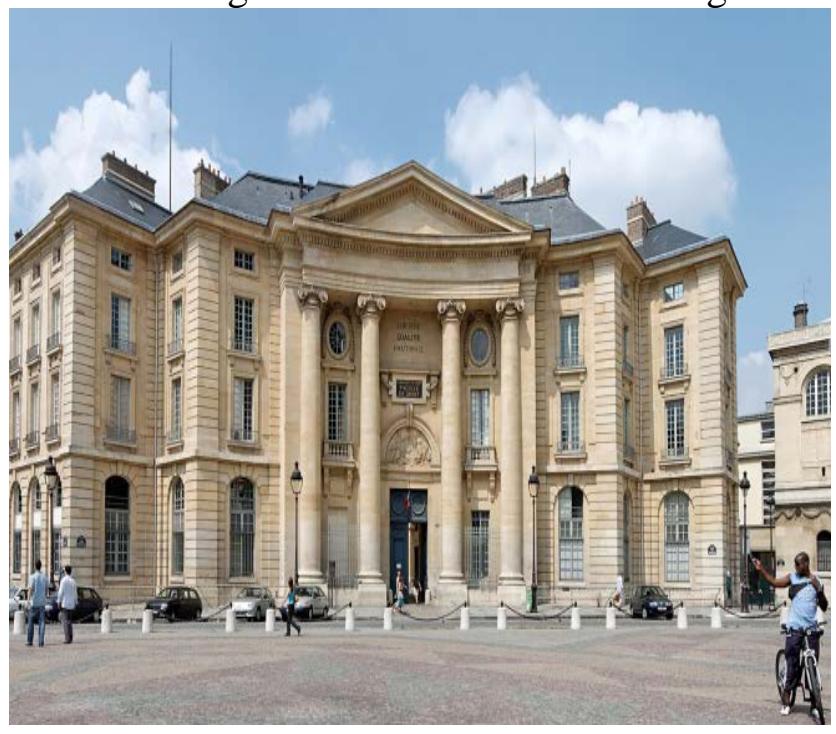

Fig. 1 The oldest University of Bologna

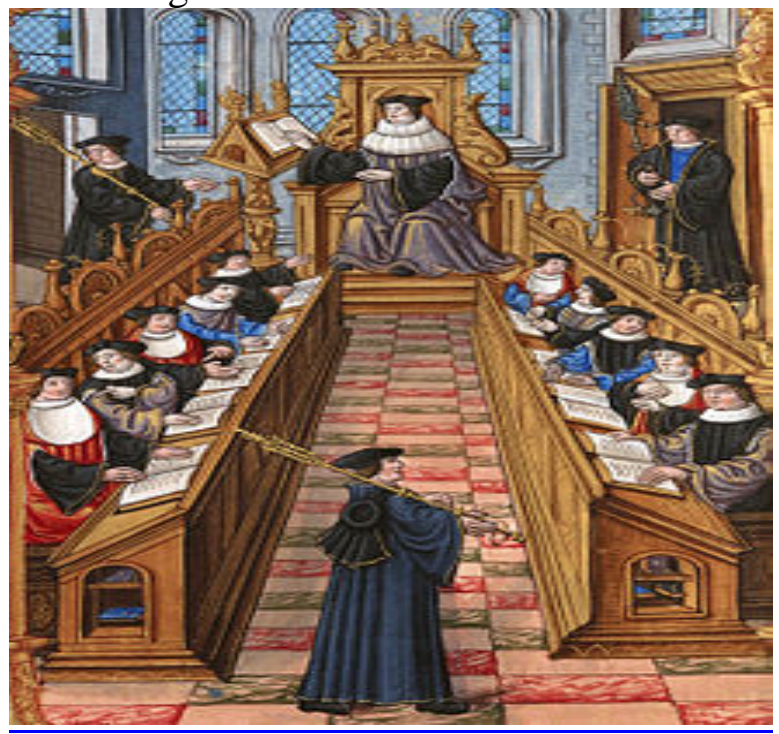

Fig. 2 a meeting of doctors at Paris University

The University of Bologna was founded in 1008 and was the first European University to establish this educational trend. The combination of structured teaching and student associations marked the origin of the studium generale. The presence of teaching legists encouraged teachers in others fields to come to Bologna. Ars dictaminis, grammar, logic, philosophy, mathematics and especially medicine 
were taught there by the middle of the thirteenth century. The university offered advanced instruction in law, medicine, and theology and had a minimum of six to eight professors teaching civil law, canonical law, medicine, logic, natural philosophy and usually rhetoric. Many professors bearing local names were learned scholars and commanding Figures in medicine and surgery. Taddeo Alderotti... (1210-1295) began to teach medicine in Bologna in about 1260. He soon raised medicine to a prestigious position in the university. The geographical distribution demonstrates the international distribution of the student body: 73\% were Italians and $26 \%$ non-Italians. The decision of the legislature of Bologna to take control of the university from the students by paying professors was probably the most important decision in the history of Italian universities. Examination of the distribution of professors offers a detailed picture of the faculty. In 1370 the university had 11 professors of civil law, 7 professors of canonical law, 3 professors of medical theory, 2 professors of medical practice (specifically of diagnosis and treatment), and 1 professor of surgery. After growing steadily, the numbers of teachers stabilized at 85 to 110 until the year 1530.[5]

\subsection{The inter-nationality of Medieval Universities in Western Europe}

The religiousness was the reason of the inter-nationality of Medieval Universities in Western Europe. Just as Bouvier said: medieval Universities in Western Europe developed according to the special living style of church. The religious doctrines of church become the fundamental principles of higher education. The common language of church was Lativ which become the teaching language. The members in universities, the staff or the students enjoying the treatment of clergy were all in-service or orientation-service. The university had the same inter-nationality with the church and religion communication. Cultivating the habit of the staff and students to live in abroad and the spirit to risk, we could know the inter-nationality from the aspect of the students. There were no limit to nation, society, wisdom or language for the students, even there was no fixed time to study. Every day was suitable time to study. The university accepts anyone who wants to learn, no matter the native or foreign, poor or rich, health or disease. Of course, the faith and moral character were the lowest requirement for students entering Medieval Universities in Western Europe. What's more, the students could learn in different universities, but they passed the certain examination before awarding degrees, which could present the equality and democracy of Medieval Universities in Western Europe.

Besides, every university had its own NATION on the base of language, politic and geography. University of Paris had 4 NATIONS: France nation, Norman nation, Picardy nation and England Nation. University of Italy had 3 NATIONS. These nations played more roles than fraternity, association, religion congregation, community and institute, becoming the most important students' communication of universities and university management organization.

University studies took six years for a Master of Arts degree (a Bachelor of Arts degree would be awarded after completing the third or fourth year). The studies for this were organized by the faculty of arts, where the seven liberal arts were taught: arithmetic, geometry, astronomy, music theory, grammar, logic, and rhetoric.[8]All instruction was given in Latin and students were expected to be able to converse in that language.

\section{The special response towards external world of Medieval Universities in Western Europe}

There is no doubt that Medieval Universities in Western Europe had the mission to cultivate for a certain industry. It means the education has the feature of occupation. Medieval University cultivated the social elite to serve the governing class. Medieval University and today's university and the Medieval were an important period of the birth and development of university degree system.

\subsection{The education occupation of Medieval Universities in Western Europe}

The main character of Medieval Universities in Western Europe was putting professional training as its goal. The medieval university was the necessary production of civilization of Greece and Rome and development of higher education. On the other hand, the birth of medieval university meets the needs of the society towards the advanced specialized talents, with strong occupation features. 
Medieval Universities in Western Europe obtained the permit of the government, put the dispersive scholar actives to collect, and became the education organization with the discipline and management. From the cultivating talents, Medieval Universities in Western Europe were occupational universities to some extent. They cultivate the students to master certain knowledge for their later job in lay, medicine, teaching or clergy. And the theology was studied by few in universities, for the most brilliant students in universities. From the requirement of the society, all wakes of life hoped to obtain the support of wisdom and subject knowledge. [6]The pope and the bishop the university cultivated qualified the theologist and lawyer to safeguard the status of Christian; the common rulers and the queen hope to consolidate their rule through drawing over more talents. Every commonwealth and city needed lawyers to cope with law dispute, servants to serve the move of the city. And the residents hoped that their sons could choose a suitable vocation, even the university professor hoped that his subject could get acceptance. Of course, there was a premise that you must obtain suitable degree which had become a judgment standard of social stratification.

\subsection{The beginning of degree in Medieval Universities in Western Europe}

Master, doctor and professor had the same meaning in Medieval. In early Paris University and other universities based on the model of Paris University, master was appellation of the theology, doctor and literature department to the teachers, the appellation of professor was used sometimes, but the appellation of doctor was rarely used. In Bologna University, the staff in law department liked to use the appellation of doctor, but rarely of master. In later, there were difference between the appellation of doctor and master.

In medieval, to some people, obtaining the qualification of teaching in universities after getting the degree was the final goal, but an effective way to improve the social status, a preparation of starting new vocation. In medieval universities, no matter master, doctor or bachelor's degree, the students must assume a certain amount teaching jobs before obtaining them. [7]However, some people stayed in universities after they finished their teaching jobs, the purpose of which was to collect money for the later learning or waiting for better chance to work.

\section{Conclusion}

Putting the teaching and examination closely together was the best creation and character for the medieval university, which was the direct statement of western scholar towards the medieval university. In fact, the medieval university was the peculiar production of Western Europe, which was one of the most valuable and rich-able heritage left to modern society by the medieval university. Modern university inherits most features from the medieval university. For example, the appellation of university was inherited; secondly, the concept of learning course, the subject and time of learning were all assured, and the results were assessed through the examination, after through the examination, they could obtain suitable degrees; thirdly, the organization of department was inherited, and the boarding system had stayed for more than 900 years. Finally, the mission of university which is training students, keeping learning and pursuing truth will never change.

\section{References}

[1] Encyclopaedia Britannica: History of Education. The development of the universities.

[2] De Ridder-Symoens 1992, pp. 47-55

[3] Cobban, A.B. English University Life in the Middle Ages[M]. Ohio State University Press, 1999.

[4] Ebyond, F\&A, Rrowood, the History of Philosophy of Education Ancient and Medieval[M]. Englewood Cliffs, Pretice-Hall Ing 1940.

[5] Romero-y Huesca Andrés, Soto-Miranda Miguel Angel, Ponce-Landín Francisco Javier, Moreno-Rojas Juan Carlos. Foundation and organization of the University of Bologna from the XII century to the Renaissance[M].Cirugia y Cirujanos, 2007, Vol.74 (5), pp.397-404 
[6] M. Preston-Shoot, J. McKimm. Prepared for practice? Law teaching and assessment in UK medical schools[J]. Journal of Medical Ethics, 2010, 36(11).

[7] H. Rashdall, The Universities of Europe in the Middle Ages, 3 Volumes, F.M. Powicke, A.B. Emden (Eds. of 2nd Edition), Oxford University Press, 1936. 